\title{
THE TREND OF WORK FROM HOME AND ITS ADVANTAGES AND DISADVANTAGES DURING THE COVID-19 PANDEMIC: A COMPARATIVE STUDY
}

\author{
aIŘÍ KUČERA, ${ }^{\mathrm{b}} \mathrm{TOMÁŠ} \quad$ KRULICKÝ, $\quad{ }^{\mathrm{C}}$ PETRA \\ NAVRÁTILOVÁ \\ ${ }^{a, b, c}$ Institute of Technology and Business in České Budějovice, \\ School of Expertness and Valuation, Okružní 517/10, 37001 \\ České Budějovice, Czech Republic \\ email: ${ }^{a}$ kuceraj@mail.vstecb.cz, ${ }^{b}$ krulicky@mail.vstecb.cz, \\ ²4112@mail.vstecb.cz
}

Abstract: This paper focuses on working from home during the COVID-19 pandemic. It focuses mainly on the advantages and disadvantages of this way of working, as well as its impact on the psyche and performance of employees and, last but not least, its impact on a company's finances. It uses the synthesis of data found on the internet, impact on a company's finances. It uses the synthesis of data found on the internet, from selected reliable sources dealing with the same or similar issues. From these sources it is evident that the effects of working from home are rather negative. The most frequently mentioned advantage is the saving of time, caused mainly by the absence of commuting to the office. The most frequently mentioned disadvantage is the absece of personal cony could feel the most is the extension of the length of communication between employees, and thus the extension of work processes. At first glance, it might seem that a company will save money using this form of work, but the reality is that the company's costs may even increase. This is due to the fact that most companies have chosen to work from home only partly, so the costs of running the offices remain the same or slightly reduced at best, and legislation states that the company must reimburse workers for costs incurred by this form of work. It follows from this contribution that, if possible, workers and employers should avoid the practice of working from home, even though it has a positive effect on the pandemic. The potential for further research could be to compare the results of this work with the same research conducted outside of the pandemic.

Keywords: work from home, COVID-19, pandemic, psyche, finance, human resources

\section{Introduction}

Work from home, also known as home office or remote work (or teleworking) has been a trend for many years in an incredible number of companies of all fields and sizes. In the last year, however, this trend has increased dramatically, due to the current pandemic situation. There are many reasons for this increase, but this form of work also has its disadvantages. This topic is very current, and no one knows how long it will stay that way.

Even assuming that Covid-19 mainly affects people of retirement age, younger people are also a high-risk group, as they may not have a severe course of the disease, but they can function as so-called carriers of this virus. This is due to their contact with other people at work. Companies and the government are trying to prevent this spread.

Krastev (2020) mentions a worrying report from the US, which states that up to $52 \%$ of people under the age of 45 have lost their jobs, been sent on holiday or their working hours have been reduced as a result of a pandemic. This, of course, adversely affects the economic situation of households and thus the economy as a whole.

Most companies plan to keep the increased option to work from home in 2021, compared to the situation before the pandemic. The most common option is 50\% remote work and 50\% standard on-site work. Related to this is the fact that up to a fifth of employers have provided a subsidy to people working from home (Vojteková, 2020).

Working from home is not only caused by the pandemic situation, but it has existed for many years and many companies have offered and still offer this form of work. Previously, work from home was offered more as a bonus for employees, now it is a bonus for the company, employees and the whole nation. Previously, some employers offered the opportunity to work from home as a bonus for gaining new employees and their satisfaction.

The aim of this paper is to find and justify the advantages and disadvantages of home office in a pandemic situation. Furthermore, find out whether the home office is a good choice in terms of the psyche of employees and their performance. The next goal is to find out whether the work from home option can reduce a company's costs and whether it is possible that this reduction will help the company enough to avoid lay-offs.

To meet the aim of this paper, the following research questions have been identified.

RQ1: What are the advantages of work from home?

RQ2: What are the disadvantages of work from home?

RQ3: Can work from home save the company enough costs so that it does not have to lay off employees even in the current situation?

RQ4: What effect does work from home have on employees?

\section{Literature research}

The pandemic has caused millions of illnesses and deaths around the world, prevented children from going to school on a regular basis, forced workers to work from home, countless people have lost their jobs (especially in service sector) and countless businesses have closed. As a result, families have to take more care of children, older family members, and other loved ones, which takes a lot of time (King et al. 2021; Horák, Mlsová a Machová, 2021).

The spread of the disease was caused mainly by travel and human movement and contact in general, so the government sought to reduce these causes with the first measures against the spread of the coronavirus.

The initial rapid spread of the Covid-19 virus was mainly due to global human movement, and initial measures therefore focused mainly on limiting this movement. Reducing human contact by reducing the number of people in the workplace was therefore a good strategy to slow the spread of the virus (Shaaw et al. 2021). As a result, many employers have decided, in part or fully, to move from offices to working from home as part of the measure. For occupations where there was no such change, there may instead have been a reduction in the number of employees in the workplace. However, these measures were not effective enough, so we are still struggling with this pandemic a year later. Due to the long presence of this disease, and the associated measures against its spread, we must also deal with its consequences. The consequences mean not only the loss of loved ones or health complications, but also other consequences that are not so obvious at first glance. One of the consequences is the increase in "laziness" of the population. Thanks to the expansion of work from home and thus an increase in the number of days of working at home, the physical activity of people working from home has decreased. This is due to the increase in time spent at home at work and the absence of mild activity associated with traveling to work (Koohsari et al. 2021). However, the increase in time spent sitting does not only apply to those who have moved to working from home, but also to others. For people who still travel to work, this commute has remained practically the only way to exercise. The government's measures, which were sometimes beyond the sustainability of the rule of law, have either banned everything else or made them so unpleasant that people turn away from these possibilities (Vrtíková, 2020).

Restricting human contact and making most leisure activities virtually impossible has a slightly positive impact on the pandemic, but a negative impact on our mental health. A survey conducted in Spain, examining the effects of the pandemic on the mental health of adults, shows that women and young people reported an increase in anxiety, depression and conflicts between work and family relationships, while men on the other hand reported greater emotional stability. This survey further states that office work is mainly related to anxiety, while work from 
home is mainly related to depression (Lopez-Nunez et al. 2021). However, mental health problems are not the only thing that can happen to us in this situation. A study in Turkey found that sleep quality also deteriorated during the pandemic, especially among women or those who lost their jobs during the pandemic (Duran and Erkin, 2021)

The fact that countless people have lost their jobs has not only psychological consequences and a deterioration in the quality of sleep, but also economic consequences. However, the economy is not only affected by the layoffs and the collapse of companies, but the pandemic in general affects the whole economy. Due to the economic impact of the Covid-19 pandemic, poverty in Uruguay has risen by more than $38 \%$, specifically from $8.5 \%$ to $11.8 \%$. Government assistance had a positive but limited effect on this increase (Brum and De Rosa, 2021).

But the economy is not everything. School closures due to the pandemic affect not only students but also their parents. Mothers whose children are in primary school are more likely to work remotely and their fathers less often, while parents who have children in closed secondary school are not affected at all. However, this situation inevitably increased inequality in childcare (Yamaamura and Tsustsui, 2021). However, this situation raises a much bigger problem. The Covid-19 pandemic may undermine the pursuit of gender equality between men and women, thanks to the unequal division of labor and thus the damage to women's living conditions. This is due to the unequal division of labor (domestic work, childcare, paid working time, personal time) during the lockdown period, when women take more care of the household and children, while men pay more attention to themselves and their work. In the fact, women's position is often even targeting by misogynistic practices at their workplaces (Waddell et al. 2021; Ranki et al. 2018; Lazaroiu, Rowland and Bartošová, 2018). However, the worst problem is the increase in domestic violence. Croda and Grossbard (2021) says that as a result of school closures, the introduction of work from home and massive layoffs/closures, there has been an increase in domestic violence. As a result, all the changes contributed to the traumatic states and were at the expense of mental health and general well-being.

The worse the mental state of an individual, the easier it is to manipulate or frighten him. All the aforementioned consequences can contribute to the mass hysteria caused by the constant supply of negative news from social media and information media (internet, television, radio, etc.). Mass hysteria caused by negative information disseminated by the media and social networks can cause governments to make mistakes. The larger the country, the worse the situation (Bagus, Pena-Ramos and Sanchez-Bayon, 2021; Lazaroiu, Horák and Valášková, 2020). The theory of conservation of resources could be a prevention against the emergence of mass hysteria. This theory assumes that proactive coping and focus on the future are crucial and affect the ability to adapt to stressful situations. This has a positive effect on perceived labor productivity during the pandemic, assuming the use of work from home (Chang, Chien and Shen, 2021).

As already mentioned above, many employers switched to work from home, mainly due to anti-pandemic measures. Jobs that at first glance do not have this option have also switched to this form of work. An example of this could be medicine, which has partially switched to so-called telemedicine (Record et al. 2021). Although it does not seem so, telemedicine (or telephone treatment) is a praised alternative to a doctor's visit. Of course, only simple cases, such as colds, etc., can be treated in this way. But even so, it was possible for doctors to save time in this way by diagnosing these simple cases. It could be said that doctors were allowed to partially move to work from home, when in fact this is not exactly true, thanks to their commitment to the fight against coronavirus.

But there is also one big catch. Work from home is not possible in all professions and not for everyone, due to insufficient internet connection, etc., and therefore this possibility of work is relatively unfair. However, it is a great opportunity to distance oneself from other people, but it is necessary to realize that there are professions when home office is not possible and at the same time workers are close to each other, so it is necessary to take this into account when creating anti-pandemic measures (Berniell and Fernandez, 2021). In addition, work from home has other advantages and disadvantages. Data from 29 European countries show that the main advantages of home office include a balance between personal life and work, higher work efficiency and better work supervision, while disadvantages include work restrictions, job insecurity and insufficient tools for work (Ipsen et al. 2021).

Work from home advantages also include flexible working hours. This flexibility lies in the fact that the worker can determine when he will work. This also has its rules, but it is a big bonus for the worker. Older students who are trained for fixed working hours will probably not appreciate this advantage, but on the contrary, younger students who are just starting to work or have been working for only a few years and have not yet become accustomed to it will appreciate this advantage. Young people in Hungary prefer partly flexible working hours and in Romania fully flexible working hours. At the same time, young people, regardless of the country, think that a compromise can be found between work and leisure, it is only a matter of perspective (Musinszki et al. 2020).

However, work from home is nothing new. It has existed for many years and has been used mainly as a bonus for employees. Now the view of this form of work has changed, thanks to the pandemic. Now work from home is almost a matter of course. Work from home also has a new form, so-called Work from anywhere. This form of work allows workers geographical flexibility in choosing a place to live. This form of work caused an increase in output of $4.4 \%$ compared to a traditional work from home, without increasing overwork (Choudhury, Foroughi and Larson, 2021). This new form of work allows workers to live almost any length of distance away from the office thanks to the fact that they do not commute to work, but only work from home. This fact also allows companies a wider selection when recruiting, as they are not limited by location.

\section{Data and methods}

The data needed to find answers to the research questions can be found on the Internet. We will select only reliable sources, i.e. from reliable websites that deal with this topic, or deal with topics such as economics, human resources, etc.

The Dittmann.cz website is the website of the Dittmann Consulting company, which deals with the transfer of psychological knowledge into practice in the field of human resource management. On this website we will find an article directly related to this topic, and other related articles. Jobs.com is known for finding vacancies but are less known for their HR articles. The Businessinfo.cz website is dedicated to business and exports, and one of its operators is the Ministry of Industry and Trade. www.bozpinfo.cz deals with the topic of safety and health at work. The E15 website deals with financial issues, specifically, the Finexpert magazine publishes articles here. The HRNews website brings together managers and specialists in the Czech Republic. It deals mainly with human resources and recruitment. It is a website that is part of Linkedin websites.

We will select the required information from these websites and synthesize them. The analyzed text must provide answers to the research questions we ask.

\section{Results}

A survey conducted by Dittmann.cz, conducted on a sample of respondents from a selection of different market segments, shows that almost $90 \%$ of respondents worked from home during the pandemic. $76 \%$ of respondents believe that the efficiency of their work from home was either the same or even higher than work in the office, only $21 \%$ believe that their 
efficiency when working from home has decreased. $45 \%$ of the interviewed managers stated that their company did not have any new rules for employees working from home and the same percentage of managers stated that in their opinion work from home is not efficient enough for the company. 69\% of the interviewed people were satisfied with working from home, the most common advantages were (in $90 \%$ of cases) time savings associated with commuting to the office (on average this saving is 60 minutes per day), then $80 \%$ stated the individual organization of work, and last but not least, not being distracted by co-workers or the absence of unnecessary meetings. The most common disadvantages were the absence of personal contact and precise boundaries of the workday (Dittmann, 2020).

According to a survey conducted by jobs-nn.cz, $16.5 \%$ of respondents were afraid of losing their job in the autumn of 2020, while at the beginning of spring 2020 it was $22.1 \%$. People also prefer full time employment to self-employment, and the interest in part-time work and own projects is also declining, due to the coronavirus crisis (www.jobs-nn.cz, 2020).

Survival.com reports that before the Covid-19 pandemic, as many as $16 \%$ of respondents had no experience with working from home, $25 \%$ worked from home less than once a month, and only $11 \%$ worked from home full time. $64.6 \%$ of respondents are inclined to the fact that work from home satisfies them completely, only $3.5 \%$ are not satisfied at all. The answers to the question of whether respondents want to return to the office are very balanced. The vast majority of respondents stated that communication with colleagues is more difficult at this time if they are working from home. $67 \%$ of respondents state that they are better at using breaks, but most respondents (69\%) stated that the biggest advantage for them is the absence of commuting to work. This survey also looks at a healthy lifestyle combined with work from home. As many as $69 \%$ of respondents working from home say they find time to get enough sleep, $56 \%$ try to eat healthily and $50 \%$ try to be outside and breathe fresh air. It was also stated that $95 \%$ of respondents eat at home, $22 \%$ of people have their food delivered, only $14 \%$ of people stated that they have not changed anything in their diet (www.survio.cz, 2020).

The benefits that are of the greatest interest among job seekers during the pandemic include, in particular, flexible working hours, bonuses or other financial benefits, 5 or more weeks of vacation and, in the case of blue-collar positions, also meal vouchers. In addition to these benefits, there is a growing effort to protect one's health, which is why there has been an increase in interest in work from home, sick leave, company cars and above-standard health care. The pandemic also led to a higher rate of providing sick days, or sick leave. In March 2020, this option was offered by $57 \%$ of so-called white-collar employers (office and managerial workers), in July 2020 it was already $65 \%$. This benefit prevents employees with the first symptoms of illness from coming to the office and infecting other colleagues, so it can be expected that the offer of this bonus will continue to increase. Almost $90 \%$ of survey respondents from the ranks of the so-called blue-collar workers (laborers, etc.) and up to $95 \%$ of workers from the ranks of the so-called white-collar workers (Grafton Recruitment, 2020) are interested in this bonus.

However, the legislation says that work from home cannot be enforced or ordered. It must be an agreement between the employer and the employee. However, employees must be reimbursed for the costs associated with work from home, so the employer should calculate these costs and include them in the work agreement for the work from home regime. Work from home employees may also be entitled to meal vouchers (Hrubá, 2020). As already mentioned, work from home brings costs to employees, such as heating, electricity or flushing. These costs amount to approximately 1,469 CZK per month (depending on the price of energy and water, etc.). Larger families, who are forced to be at home, will have higher costs, while the increase in their costs is almost impossible for single-person households (Poncarová, 2021).
However, work from home also has a negative effect on the creativity of employees. Conversations between employees, which took place, for example, in the office kitchenette, are not just a waste of time, they also bring creativity, spontaneous ideas and innovations. Loss of creativity can have a negative effect on the company and the psyche of employees (Gopas and Welcome to the Jungle, 2021).

The vast majority of workers commute to the workplace, but almost a third could utilize work from home if the employer allowed them to do so and provided them with the necessary equipment. Most employed people in the Czech Republic would appreciate the possibility of at least occasional work from home. At the same time, half of Czechs believe that their work from home option will remain even after dealing with the pandemic (Hájková, 2021).

In Graph No. 1 we see the most frequently mentioned advantages of work from home according to residents of the Czech Republic.

Graph 1 : Advantages of work from home

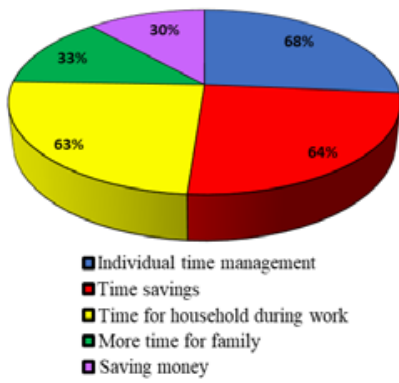

Source: www.hrnews.cz, own interpretation.

It is clear from this graph that the biggest advantage is the individual distribution of time for work and personal life (68\%), which allows workers, for example, to have a sufficiently long sleep. Another great advantage is the saving of time (64\%), caused mainly by the absence of commuting to work, the absence of having to do grooming and make-up, etc. In close connection is the possibility to take care of the household while "at work" (63\%). Much less often mentioned is the benefit associated with more time for family (33\%). Similarly, there is an advantage in the form of saving money, again caused by the absence of commuting (30\%).

In Graph No. 2 we can see the most frequently mentioned disadvantages of work from home, mentioned by the citizens of the Czech Republic.

Graph 2 : Disadvantages of work from home

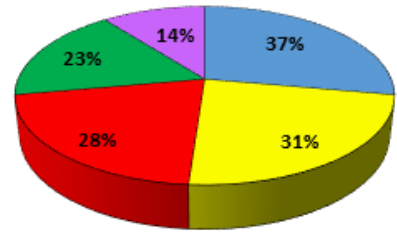

A Absence of personal contact with coworkers QPoor communication with colleagues

Insufficient household equipment for work

口Issues with time management

QDisuption and distraction by family

Source: www.hrnews.cz, own interpretation.

The biggest disadvantage for employees is the absence of contact with co-workers and generally less personal contact with people (37\%). In second place is the poor communication with other coworkers $(31 \%)$, which complicates the work. Another huge disadvantage and complication at work is insufficient household 
equipment for work (28\%), people most often lack better technology or faster internet. Poor organization of time can also be a common problem for employees (23\%), when employees make it harder to distinguish between personal time off and working time. This can lead to a lack of personal time and related workaholism, or, conversely, insufficient discipline/motivation to work, the associated low efficiency and the possibility of losing the job. The least frequently mentioned, but no less serious problem is distraction by the family (14\%), especially by children. This can lead to a lack of concentration on work, a higher incidence of errors, or a reduction in efficiency.

\section{Discussion}

At the beginning of this paper, we asked these research questions and then found answers to them.

\section{RQ1: What are the advantages of work from home?}

The most mentioned advantages of work from home can be found in Graph No. 1. Overall, various research shows that $69 \%$ of people who work in this way are satisfied with this form of work. The most common advantages are time savings, which employees can use, for example, for better rest. This advantage is mainly due to the absence of commuting to work, or the time saved by not having to get ready for work in an office (dressing, make-up, etc.). Even though most people working from home do not groom for their work duties, experts will tell you that personal adjustments (dressing well, make-up, etc.) can increase our productivity and work confidence. Other advantages were, for example, the possibility of planning one's own time determining when one will work and when one will have personal time off. Less frequently mentioned advantages include saving money, time for household and family even during working hours or, for example, not being distracted by coworkers or the absence of unnecessary meetings. The pandemic caused an increase in interest in work from home due to greater interest in health protection.

\section{RQ2: What are the disadvantages of work from home?}

All the advantages of work from home are certainly attractive, but it is necessary to realize that this form of work also has its disadvantages. The most common of them can be seen in Graph 2. The most frequently mentioned disadvantages include poorer communication with co-workers, which can greatly complicate work and also cause work frustration for employees, as well as greater time consumption of work. However, the most frequently mentioned disadvantage is the absence of personal contact with people, whether with co-workers, clients or generally less contact with people, which can cause mental or social problems for workers. The most obvious disadvantage of work from home is undoubtedly the lack of household equipment for work. Households often lack sufficient quality technology or, for example, a fast enough internet connection. Probably the worst disadvantage is the problems with the organization of time, when workers make a harder distinction between working time and time off. This can cause workaholism or poor performance. A big disadvantage, especially for workers who have children, is distraction by family at work. The disadvantage that no one mentions, and probably does not even realize, is the increase in costs incurred by the worker. These costs amount to up to 1,469 CZK per month.

RQ3: Can work from home save the company enough costs so that it does not have to lay off employees even in the current situation?

Although work from home is a form of work that can save a company money by cutting the operation of offices, etc., most companies do not implement work from home for all $100 \%$. They prefer a combination of office work with working from home. However, due to the epidemic, not all employees have work from home at once (the company works so that, for example, $50 \%$ of employees are working from home and the remaining $50 \%$ in the office), so that it does not happen that all employees are in the office at once, not even once a week. Thanks to this, the savings for the company are minimal to zero. In addition, the law states that in the case of work from home, the employer is to reimburse the employee for their costs of this form of work. These are, for example, greater consumption of water, electricity, heat, etc. These costs for employees amount to a little less than CZK 1,500 per month. In addition, complications caused by this form of work can reduce the quality of work and reduce employee productivity. It follows that work from home cannot save companies enough costs to prevent redundancies.

\section{RQ4: What effect does work from home have on employees?}

In general, most employees are satisfied with work from home, but there are also those (3.5\%) who are absolutely dissatisfied with work from home. Although this form of work has a positive effect on the epidemic, it can cause workers relatively serious psychological problems such as workaholism, problems associated with a lack of social contact with other people, poorer sleep or insufficient motivation. The current situation also means that the number of people who are afraid of losing their job is still growing. Thanks to more time spent at home, the number of cases of domestic violence has also increased. In general, therefore, the combination of the current epidemiological situation, social distancing, distance learning of children and work from home is not ideal for workers and can cause them problems. On the other hand, some people decided to pay more attention to their lifestyle, for example, so that people started going out to nature regularly, exercising regularly or started cooking at home or cooking healthier. However, the disadvantages still prevail.

A newly raised question could be what effect it has on employees, for example, working in a bad team environment in the office compared to working in one from home. Alternatively, what effect would this form of work have on employees if the Covid-19 epidemic were not taking place in the world? Thanks to this epidemic, one more question should be asked, and that is the effect of the epidemic on workers whose work is not able to be done at home (e.g. sales clerks, some medical staff, or laborers) who are not covered by this contribution.

These results could help companies decide whether or not to provide the opportunity to work from home. They could also help employees decide whether or not to accept to this form of work.

\section{Conclusion}

The aim of this work was to find and justify the advantages and disadvantages of work from home in a pandemic situation, then to determine the impact of this style of work on the psyche and performance of employees and to determine the effects of this form of work on company finances. This goal was fulfilled within the scope of this paper.

In this article, we found the most frequently mentioned advantages and disadvantages of employees, but also those that most employees do not perceive. We also found that the impact of working from home with other anti-pandemic measures and the pandemic situation around us is rather negative. Not only can this situation affect people's psyche, but it can also affect physical health. Despite the fact that negative influences prevail, there are also those who, thanks to this situation, have decided to go towards a "healthier" way of life, such as starting to exercise, eating healthier, taking walks in nature or relaxing more. However, these advantages can also lead to a reduction in work ethic. This is not helped by the presence of children or other family members at the time when the employees decide to work. If we are to name the most serious negative influences of work from home, we should definitely mention a higher risk of workaholism or a higher risk of domestic violence. The more visible problems are mainly poor communication with coworkers and the resulting delay in work or, for example, the 
absence of contact with co-workers, customers and other people in general. As for the influence of the working from home on the psyche of employees, it can be said that many surveys show that this influence is negative, but it is very individual, especially in the responses. The pandemics and other related facts often cause fear of the future, worse sleep or various mental illnesses, such as depression, etc.

As for the impact on employee performance, it is again a very individual matter. In general, however, employee performance is the same in most cases. However, it can happen that the work takes more time for employees, due to the emergence of technical problems, or due to the extension of communication between co-workers, due to the fact that they have to communicate electronically.

The influence of work from home on the company's finances is minimal. Allegedly, a company can save money on office maintenance, but the reality is different. Most companies have chosen the option of work from home combined with going to the office (e.g. 1 day a week in the office, the rest of the week work from home), and most often in such a way that there are only part of the office staff, which means that the offices are practically in the same mode of operation during the whole week, so the savings are minimal. This saving is practically zeroed by the fact that according to the legislation, the employer must pay the newly incurred costs to the employee, which are not exactly small (specifically, it is almost 1,500 CZK per month per employee). Therefore, it is not possible for a company to save a sufficient amount of money by setting up work from home, not having to lay off redundant employees if necessary.

To meet the goals of this work, we have used a number of studies, surveys and expert papers that deal with the same or similar topic.

The main limitations of this work would be the short-term nature of all the surveys, as the pandemic is a relatively "fresh" topic, so there is less evidence that all the impacts mentioned in this paper are actually caused by work from home.

The main complications included the difficulty of finding resources to meet the goals of this work. This was mainly due to the relative novelty of the topic. As a result, it was even more difficult to choose really good sources for this work.

As a potential for further research, we see the attractiveness of comparing the same data from outside the pandemic timeframe and this research. Alternatively, the impact of work from home outside the pandemic on employees in terms of mental health, performance or their approach to life management.

The lesson for employers from this work is that work from home has a positive effect against the spread of the disease, but a negative effect on employees and the speed of their work. For employees, on the other hand, that work from home should be avoided if possible.

\section{Literature:}

1. Bagus, P; Pena-Ramos, J. A., Sanchez-Bayon, A.: COVID19 and the political economy of mass hysteria. International Journal of Environmental Research and Public Health. 18(4). ISSN 1660-4601.

2. Berniell, L., Fernandez, D.: Jobs' amenability is not enough: the role of household inputs for safe work under social distancing in Latin American cities. World Development. 2021, 140. ISSN 0305-750X.

3. Brum, M., De Rosa, M.: Too little, but not too late: nowcasting poverty and cash transfers incidence during COVID19's crisis. World Development. 2021, 140. ISSN 0305-750X.

4. Chang, Y. H., Chien, C. J., Shen, L. F.: Telecommuting during the coronavirus pandemic: Future time orientation as a mediator between proactive coping and perceived work productivity in two cultural samples. Personality and Individual Differences. 2021, 171. ISSN 0191-8869.
5. Choudhury, P., Foroughi, C., Larson, B.: Work-fromanywhere: the productivity effects of geographic flexibility. Strategic Management Journal. 2021, 42(4), 655-683 p. ISSN 0143-2095.

6. Croda, E., Grossbard, S.: Women pay the price of Covid- 19 more than men. Review of Economics of the Household. 2021, 19(1). ISSN 1569-5239.

7. Dittmann L., 2020, [online] Available at: https://www.ditt mann.cz/wp-content/uploads/report_pruzkum-home-office-covi d-19_dittmann-consulting.pdf

8. Duran, S., Erkin, O.: Psychologic distress and sleep quality among adults in Turkey during the COVID-19 pandemic. Progress in Neuro-Psychopharmacology \& Biological Psychiatry. 2021, 107. ISSN 0278-5846.

9. Hájková, A., 2021, [online] Available at: https://www.hrne ws.cz/lidske-zdroje/trendy-id-148711/fenomen-home-office-vcislech-jak-se-nam-pracuje-z-domova-id-4002093

10. Horák, J., Mlsová, K., Machová, K.: Impact of the coronavirus pandemic on the tertiary sector. Littera Scripta. 2021, 14(1), 28-39 p. ISSN 1805-9112.

11. Hrubá, K., 2020, [online] Available at: https://www.bo zpinfo.cz/home-office-jeho-legislativni-psychosocialni-aspektyv-souvislosti-s-covid-19-0

12. Ipsen, C., Van Veldhoven, M., Kirchner, K., Hansen, J. P.: Six key advantages and disadvantages of working from home in Europe during COVID-19. International Journal of Environmental Research and Public Health. 2021, 18(4). ISSN 1660-4601.

13. King, E. M., Randolph, H. L., Floro, M. S., Suh, J.: Demographic, health, and economic transitions and the future care burden. World Development. 2021, 140. ISSN 0305-750X.

14. Koohsari, M. J., Nakaya, T., Shibata, A., Ishii, K., Oka, K.: Working from home after the COVID-19 pandemic: do company employees sit more and move less? Sustainability. 2021, 13(2). ISSN 2071-1050

15. Krastev, I.: Už je zítra? Aneb, jak pandemie mění Evropu [Is it tomorrow? In other words, how a pandemic is changing Europe]. Prague: Karolinum, 2020. ISBN 978-80-246-4647-3.

16. Lazaroiu, G., Horák, J., Valášková, K.: Scaring ourselves to death in the time of covid-19: pandemic awareness, virus anxiety, and contagious fear. Linguistic and Philosophical Investigations. 2020, 19, 114-120 p. ISSN 1841-2394.

17. Lazaroiu, G., Rowland, Z., Bartošová, V.: Gendered power disparities, misogynist violence, and women's oppression: the \#metoo movement against workplace sexual harassment. Contemporary Readings in Law and Social Justice. 2018, 10(2), 57-63 p. ISSN 1948-9137.

18. Lopez-Nunez, M. I., Diaz-Morales, J. F., Aparicio-Garcia, M. E.: Individual differences, personality, social, family and work variables on mental health during COVID-19 outbreak in Spain. Personality and Individual Differences. 2021, 172. ISSN 0191-8869.

19. Musinszki, Z., Vallasek, M., Melypataki, G., Csolak, E. H., Liptak, K.: Workaholism and a new generation - labour market survey among Hungarian and Romanian youth. Amfiteatru Economic. 2020, 22, 1227-1242 p. ISSN 1582-9146.

20. Poncarová, J., 2021, [online] Available at: https://www.e1 5.cz/finexpert/vydelavame/kolik-vas-stoji-home-office-a-jakusetrit-za-energie-1378530

21. Ranki, C., Vrbka, J., Valášková, K., Olah, J.: Objectifying women's bodies in the workplace: gender-based misconduct, egregious sexual pressure, and misogynistic practices. Contemporary Readings in Law and Social Justice. 2018, 10(2), 71-77 p. ISSN 1948-9137.

22. Record, J. D., Ziegelstein, R. C., Christmas, C., Rand, C. S., Hanyok, L. A.: Delivering personalized care at a distance: how telemedicine can foster getting to know the patient as a person. Journal of Personalized Medicine. 2021, 11(2). ISSN 20754426.

23. Redaction Jobs Metwork News, 2020, [online] Available at: https://www.jobs-nn.com/pruzkum-49-firem-preslo-na-homeoffice-ci-remote/

24. Redakčně upravené tiskové zprávy počítačové školy Gopas a společnosti Welcome to the Jungle [Edited press releases of Gopas Computer School and Welcome to the Jungle], 2021, 
[online] Available at: https://www.businessinfo.cz/clanky/homeoffice-riziko-pro-produktivitu-i-pro-kybernetickou-bezpecnost/ 25. Shaaw, A. K., White, L. A., Michaalska-Smith, M., Borer, E. T., Craft, M. E., Seabloom, E. W., Snell-Rood, E. C., Travisano, M.: Lessons from movement ecology for the return to work: modeling contacts and the spread of COVID-19. Plos One. 2021, 16(1). ISSN 1932-6203.

26. Survio, 2020, [online] Available at: https://www.surv io.com/cs/blog/novinky/home-office-pruzkum/

27. Tisková zpráva agentura Grafton Recruitment [Grafton Recruitment press release], 2020, [online] Available at: https://www.businessinfo.cz/clanky/koronavirus-zmenil-benefit y-zamestnanci-chteji-sluzebni-auta-zdravotni-dovolenou-i-ho me-office/

28. Vojteková, M. 2020. [online] Available at: https://www.li nkedin.com/pulse/firmy-bojuj\%25C3\%25BA-po\%25C4\%258D as-druhej-vlny-korona-kr\%25C3\%25ADzy-v\%25C3\%25BDsle dky-hr-vojtekova/?trackingId=XeVunO8/TZiOeL37wFiLgg \%3D\%3D\&fbclid=IwAR0OqGf3lieS16KFL6oK_79Nl48m8riY K3shp8CbaTaOm85W4UojqHkUDsA

29. Vrtíková, K.: Human rights, freedoms and the limits of their limitation in a time of pandemic. Littera Scripta. 2020. 13(2), 111-121 p. ISSN ISSN 1805-9112.

30. Waddell, N., Overall, N. C., Chang, V. T., Hammond, M. D.: Gendered division of labour during a nationwide COVID-19 lockdown: implications for relationship problems and satisfaction. Journal of Social and Personal Relationships. 2021, 38(6), 1759-1781 p. ISSN 0265-4075.

31. Yamamura, E., Tsustsui, Y.: The impact of closing schools on working from home during the COVID-19 pandemic: evidence using panel data from Japan. Review of Economics of The Household. 2021, 19(1), 41-60 p. ISSN 1569-5239.

\section{Primary Paper Section: A}

Secondary Paper Section: AH, AO 